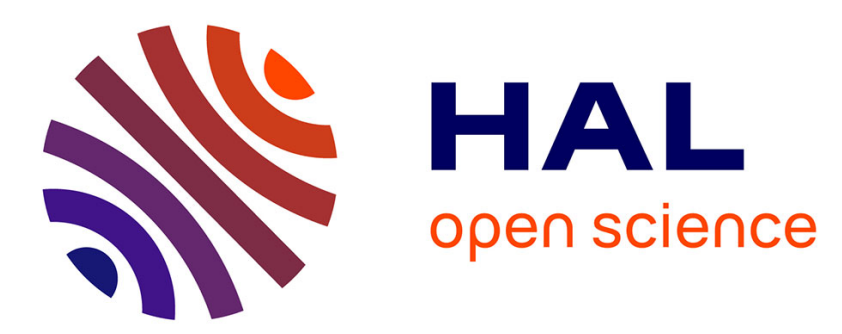

\title{
Expression of $11 \beta$-hydroxysteroid-dehydrogenase 2 in Sertoli cells of boar testes
}

Rolf Claus, Markus Lacorn, Harald Welter, Oksana Lekhkota, Nina Messe, Anna Wagner, Martin Bergmann

\section{- To cite this version:}

Rolf Claus, Markus Lacorn, Harald Welter, Oksana Lekhkota, Nina Messe, et al.. Expression of $11 \beta$ hydroxysteroid-dehydrogenase 2 in Sertoli cells of boar testes. Molecular and Cellular Endocrinology, 2007, 272 (1-2), pp.86. 10.1016/j.mce.2007.04.010 . hal-00531923

\section{HAL Id: hal-00531923 \\ https://hal.science/hal-00531923}

Submitted on 4 Nov 2010

HAL is a multi-disciplinary open access archive for the deposit and dissemination of scientific research documents, whether they are published or not. The documents may come from teaching and research institutions in France or abroad, or from public or private research centers.
L'archive ouverte pluridisciplinaire HAL, est destinée au dépôt et à la diffusion de documents scientifiques de niveau recherche, publiés ou non, émanant des établissements d'enseignement et de recherche français ou étrangers, des laboratoires publics ou privés. 


\section{Accepted Manuscript}

Title: Expression of $11 \beta$-hydroxysteroid-dehydrogenase 2 in Sertoli cells of boar testes

Authors: Rolf Claus, Markus Lacorn, Harald Welter, Oksana Lekhkota, Nina Messe, Anna Wagner, Martin Bergmann

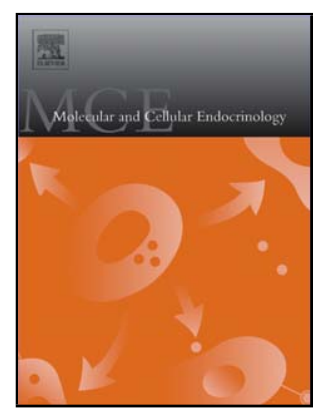

PII:

S0303-7207(07)00159-1

DOI: doi:10.1016/j.mce.2007.04.010

Reference: MCE 6644

To appear in: $\quad$ Molecular and Cellular Endocrinology

Received date: $\quad 17-10-2006$

Revised date: 20-4-2007

Accepted date: $\quad$ 21-4-2007

Please cite this article as: Claus, R., Lacorn, M., Welter, H., Lekhkota, O., Messe, N., Wagner, A., Bergmann, M., Expression of 11ß-hydroxysteroid-dehydrogenase 2 in Sertoli cells of boar testes, Molecular and Cellular Endocrinology (2007), doi:10.1016/j.mce.2007.04.010

This is a PDF file of an unedited manuscript that has been accepted for publication. As a service to our customers we are providing this early version of the manuscript. The manuscript will undergo copyediting, typesetting, and review of the resulting proof before it is published in its final form. Please note that during the production process errors may be discovered which could affect the content, and all legal disclaimers that apply to the journal pertain. 


\section{Expression of 11ß-hydroxysteroid-dehydrogenase 2 in Sertoli cells of boar testes}

Rolf Claus $^{\mathrm{a} *}$, Markus Lacorn ${ }^{\mathrm{a}}$, Harald Welter ${ }^{\mathrm{a}}$, Oksana Lekhkota $^{\mathrm{b}}$, Nina Messe ${ }^{\mathrm{a}}$, Anna Wagner ${ }^{\mathrm{a}}$, Martin Bergmann ${ }^{\mathrm{b}}$

${ }^{a}$ Institut für Tierhaltung und Tierzüchtung, Universität Hohenheim, Garbenstr. 17, 70599 Stuttgart

${ }^{\mathrm{b}}$ Institut für Veterinäranatomie, Histologie und Embryologie, Universität Gießen, Frankfurterstraße 98, 35392 Gießen

* Corresponding author: Prof. Dr. Rolf Claus, Institut für Tierhaltung und Tierzüchtung, Universität Hohenheim, Garbenstr. 17, 70599 Stuttgart, Germany, Tel.: 0049/711/459-22455, Fax: 0049/711/459-22498, e-mail: thsekret@uni-hohenheim.de 


\begin{abstract}
11ß-hydroxysteroid dehydrogenase 2 (11ß-HSD2) activity occurs in boar testes but it is not known which cell types express 11ß-HSD2 mRNA and protein. Therefore, testes samples were taken from mature boars. For immunocytochemistry and Western Blot pig specific antibodies were raised against a 10 amino acid peptide corresponding to amino acids $391-400$ of the coding sequence. Quantitative PCR was performed in testis homogenates and additionally RT-PCR in samples collected by UV-single cell microdissection. Data show that in interstitial tissue 11ß-HSD2 is expressed in Leydig cells and additionally in blood capillaries. In tubuli, 11ß-HSD2 primarily is formed in Sertoli cells whereas occurrence in spermatogonia could not be definitely proven. Because glucocorticoid receptors were never found in boar Leydig cells it is concluded that the expression of 11ß-HSD2 in several types of cells forms consecutive lines of defense to protect spermatogonia against glucocorticoidinduced apoptosis.
\end{abstract}

Keywords: pig, 11ß-HSD2 expression, Sertoli cells, testis, spermatogenesis 


\section{Introduction}

Glucocorticoids are involved in cell cycle regulation of almost every tis sue. They initiate cell differentiation, expression of cell specific genes, induce a block at the G1 phase of the cell cycle and may induce apoptosis (Geley et al., 1996; Moran et al., 2000; Riccardi et al., 1999; Sanchez et al., 1993; Thompson, 1994). Tissue specific reactions are explained by the levels of circulating cortisol and the degree of expression of the cortisol receptor. More recently, research was focussed on the 11ß-hydroxysteroid-dehydrogenase enzymes (11ß-HSD), which play a role in the pre-receptor regulation of glucocorticoid hormone action (for review see Draper and Stewart, 2005). Two isoforms were characterized: 11ß-HSD2 is a unidirectional high affinity enzyme which oxidizes active cortisol to inactive cortisone in the presence of $\mathrm{NAD}^{+}$as a cofactor (Albiston et al., 1994; Brown et al., 1993). Initially, its function in aldosterone sensitive tissues was investigated, e.g. kidney, colon, salivary, and sweat glands, where it avoids the interaction of glucocorticoids with the aldosterone receptor (Claus et al., 2001; Funder et al., 1988; Monder, 1990; Naray-Fejes-Toth and Fejes-Toth, 1995). Additionally it is well documented that expression of 11ß-HSD2 in the placenta protects the fetus against maternal glucocorticoids and thus against initiation of gene expression, catabolic processes and premature induction of birth (Klemcke et al., 2003; Seckl, 1997). Peripheral expression of $11 ß-H S D 2$, e.g. in the brain of perinatal rats, is similarly regarded to protect the brain against disturbances of glucocorticoid-dependent programming

of behavior later in life (Holmes and Seckl, 2006). A possible role for tumorigenesis was also reported due to the antiproliferative effects of glucocorticoids (Rogatsky et al., 1997) which are reduced by an increased 11ß-HSD2 expression in a number of tumors (see: Draper and Stewart, 2005).

11ß-HSD1 is a low affinity bidirectional enzyme, capable of carrying out 11-oxo-reductase reactions in the presence of $\mathrm{NADP}(\mathrm{H})$. Additionally dehydro genase activities can be carried out in the presence of $\mathrm{NAD}^{+}$as cofactor (Draper and Stewart, 2005). Usually the reducing 
function is more important (Ozols, 1995) and reactivates circulating inactive cortison to cortisol thus increasing glucocorticoid exposure to the glucocorticoid receptor (GR) e.g. in the liver where cortisol is the predominant regulator of gluconeogenesis (Monder and White, 1993).

Meanwhile the modulating role of the 11ß-HSD-isoforms was substantiated for many tissues including the testes. Basing mainly on studies in the rat, the expression of 11ß-HSD1 was demonstrated by mRNA determination and immunofluorescence studies in intact isolated Leydig cells (Ge et al., 1997; Leckie et al., 1998; Phillips et al., 1989). In mature rats the oxidative capacity prevails so that it was concluded, that an increased inactivation of glucocortidoids around puberty allows an increase of testicular androgen formation (Michael et al., 2003; Monder et al., 1994; Neumann et al., 1993). The presence of the 11ß-HSD2 isoform in rat testes was recently described and its protective role for testosterone production and expression of GR was discussed (Ge et al., 2005a).

In the pig, an effect of cortisol on testicular steroidogenesis was not substantiated so far and the GR does not occur in Leydig cells (Wagner and Claus, 2004). However, we demonstrated GR expression in spermatogonia of boar testes which is linked with a considerable degree of apoptosis limiting overall sperm yield. Moreover, inhibition of LH and thus testicular stero id formation by active immunization against GnRH led to an increased expression of GR by spermatogonia and thus an increase of apoptosis (Wagner and Claus, 2004). By determination of $113-H S D$ enzyme activity we could demonstrate the presence of high amounts of $113-$ HSD2 activity but not of 11ß-HSD1 activity in the testes of boars. Moreover the oxidizing activity was lost in testes of GnRH-immunized boars (Claus et al., 2005). A localization of 11ß-HSD2 expression in boar testes could not be performed so far because pig-specific antisera are not available. 
Basing on the complete coding sequence which had been determined already (Lange et al., 2003) it was the aim of the present study to raise antibodies and to determine the location of $11 ß-H S D 2$ expression in boar testes, specifically in seminiferous tubuli by immunocytochemistry and Western Blot. Presence of 11ß-HSD2 mRNA was further verified by real time PCR in whole testis homogenate or in individual cell types after UV-single cell microdissection followed by conventional RT-PCR.

\section{Material and Methods}

\subsection{Production of antibodies}

Antibody production was based on the peptide CPNLGSAPTAQ. This sequence was selected from the C-terminus of the complete coding sequence of porcine 11ß-HSD2 (Lange et al., 2003 GenBank Accession no. $\underline{\mathbf{A 3 7 4 4 1 4}}$ ) and corresponds to amino acids 391-400. The C-terminus is specific for the enzyme but also reveals considerable heterogeneity between species so that existing antisera from other species do not bind porcine 11ß-HSD2. A cysteine residue was inserted at the $\mathrm{N}$-terminus to perform coupling to bovine serum albumin (BSA) as a carrier protein. The peptide was commercially synthesized and checked for purity (Biolux, Stuttgart, Germany).

For coupling, $7.5 \mathrm{mg}$ BSA in $500 \mu \mathrm{L} 0.1 \mathrm{M}$ carbonate buffer $(\mathrm{pH} 8.3)$ were activated using $1 \mathrm{mg}$ of the bifunctional crosslinker reagent $\mathrm{N}$-succinimidyl-4-(maleimidomethyl)cyclohexanecarboxylate (Fluka, Germany) as described earlier (Rothbard et al., 1984). Excessive reagent was removed by Sephadex G-25 column chromato graphy. The cystein econtaining peptide ( $2.5 \mathrm{mg}$ in bidistilled water) was reduced with an equimolar amount of Tris-(2-carboxyethyl)-phosphine hydrochloride (AppliChem, Darmstadt, Germany) (Burns et al., 1991). The activated BSA solution and the reduced peptide were combined (molar ratio 1:20) and coupling was performed at room temperature for one hour. The reaction product 
was split into $0.5 \mathrm{mg}$ portions (in $50 \mu \mathrm{L}$ PBS) which were stored at $-20^{\circ} \mathrm{C}$ until used for immunization.

Two rabbits were injected initially with $0.5 \mathrm{mg}$ of the conjugate emulsified in $0.5 \mathrm{~mL}$ of Freund`s complete adjuvant and in $0.5 \mathrm{~mL}$ PBS. Half of the volume was given s.c. and half i.m.. Booster injections of $0.5 \mathrm{mg}$ of antigen emulsified in Freund 's incomplete adjuvant/PBS followed at 4-week intervals. Serum was obtained every second week starting before the first immunization (preimmune serum). A total of 6 booster injections were given and animals were bled 2 weeks after the last injection. The immunization scheme of the rabbits was approved by the local animal welfare committee.

For titer determination the peptide used for immunization was dissolved in $0.1 \mathrm{M}$ carbonate buffer (pH 9.6) at a concen tration of $10 \mathrm{ng} / \mathrm{mL}$. One hundred $\mu \mathrm{L}$ per well were pipetted into Immobilizer Amino microtiterplates (Nunc, Wiesbaden, Germany) and allowed to react for $1 \mathrm{~h}$ at $37^{\circ} \mathrm{C}$ under shaking. Plates were emptied and blocked with testing buffer $\left(0.12 \mathrm{M} \mathrm{NaCl}, 0.02 \mathrm{M} \mathrm{Na}_{2} \mathrm{HPO}_{4}, 0.01 \mathrm{M}\right.$ EDTA, $0.1 \%$ hydrolized gelatine, $0.05 \%$ Tween 20, $0.002 \%$ phenol red, $0.005 \%$ Chlorhexidine digluconate; $\mathrm{pH} 7.2$ ) overnight at $4{ }^{\circ} \mathrm{C}$. All following washing steps were performed using 10\% PBS containing 0.05\% Tween 20 . Antisera were diluted in testing buffer (1:10 000) and $100 \mu \mathrm{L}$ of each dilution per well were incubated for $2 \mathrm{~h}$ at $37^{\circ} \mathrm{C}$. For the next step, donkey-anti-rabbit IgG horserad ish peroxidase conjugate (Amersham, Little Chalfond, UK) was added at a dilution of 1:10 000 (100 $\mu \mathrm{L} /$ well) and incubated for $1 \mathrm{~h}$ at $37^{\circ} \mathrm{C}$. For color reaction Tetramethylbenzidine $/ \mathrm{H}_{2} \mathrm{O}_{2}$ in acetate buffer was used and the reaction was stopped after 40 min at $37{ }^{\circ} \mathrm{C}$ using $2 \mathrm{M} \mathrm{H}_{2} \mathrm{SO}_{4}$. Optical density (OD) was determined at 450/690 nm.

\subsection{Source and preservation of tissue}

Testes were collected from 4 sexually mature Landrace boars. They had been kept in our experimental unit and were shown by semen collection and evaluation to be sexually normal. 
They were slaughtered at an age of 32 weeks and the testes were removed. In addition aldosterone sensitive tissues (kidney, colon) which are known to express high levels of 11ßHSD2 (Claus et al., 2001) were taken from one of the boars as reference samples for validation of immunostaining and PCR. Tissue portions were taken from the middle area of the parenchyma both from testes and the kidney. They were immediately rinsed with cold physiological saline and fixed in $3.7 \%$ formaldehyde for immunocytochemical evaluation. Additional samples from testes ( 4 boars), kidney and colon (one boar) were shock frozen in liquid nitrogen and then stored at $-80^{\circ} \mathrm{C}$ for quantitative PCR and Western Blot.

\subsection{Western Blot}

One gram of each tissue was transferred into 2 volumes of ice cold lysis buffer (10 mM Tris/HCl pH 7.5, 20 mM Sodiummolybdatedihydrate, 10 mM DTT, $10 \%$ glycerol, $0.05 \%$ Triton X 100, containing the protease inhibitors Pepstatin A $(10 \mu \mathrm{g} / \mathrm{ml})$, Leupeptin (10 $\mu \mathrm{g} / \mathrm{ml})$, Aprotin in $(10 \mu \mathrm{g} / \mathrm{ml})$, PMSF $(2 \mathrm{mM}), 1 \mathrm{mM}$ EDTA $)$ and homogenized with an Ultra Turrax equipment (Jahnke and Kunkel, Staufen, Germany) for $20 \mathrm{sec}$. After centrifugation at $18.000 \mathrm{x} \mathrm{g}$ for $10 \mathrm{~min}$ at $4{ }^{\circ} \mathrm{C}$ the protein concentration in the resulting supernatant was measured colorimetrically according to Bradford (1976) against standard dilutions of bovine serum albumin. Aliquot portions $(15 \mu \mathrm{g})$ of protein from the tissues were separated on a 5$10 \%$ SDS-polyacrylamide gel and transfered to nitrocellu lose membrane $(0.45 \mu \mathrm{m}$, Schleicher and Schuell, Darmstadt, Germany) using a "Semi-Phor" semidry blotting chamber (Höfer Scientific Instruments, San Francisco). The membrane was b locked at $4{ }^{\circ} \mathrm{C}$ over night in $5 \%$ nonfat dry milk in PBS-T (0.1\% Tween 20 in phosphate-buffered saline) and then probed with a 1:2000 fold dilution of the porcine 11ß-HSD2 antiserum at room temperature for $2 \mathrm{~h}$.

Membranes were washed with PBS-T and incubated with a 1:5000 fold dilution of horseradish peroxidase-conjugated goat anti-rabbit IgG at room temperature for $1 \mathrm{~h}$, washed again 3 times with PBS-T. Immunoblots were incubated with a luminol-based detection 


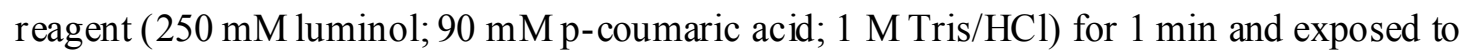
X-ray films for $30 \mathrm{sec}$. Negative control studies included the preabsorption of the 11ß-HSD2 antiserum with different concentrations of its peptide antigen $(1 \mu \mathrm{g}$ and $10 \mu \mathrm{g})$ for $1 \mathrm{~h}$ at $37^{\circ} \mathrm{C}$ as well as the replacement of the 113 -HSD2 antiserum with the preimmune serum (1:2000). Whole protein extracts from boar colon and kidney served as positive controls. A prestained protein standard (MBI, Fermentas, Germany) was used as molecular size marker.

\subsection{Histological procedures and immunocytochemistry}

The formaldehyde fixed samples were conventionally dehydrated and embedded in paraffin (Romeis, 1989). Immunocytochemical staining of 11ß-HSD2 was performed according to a standard protocol(Mentschel et al., 2001). In brief, the deparaffinized specimen were activated by heating in citrate buffer in a microwave oven. Endogenous peroxidase was blocked with $3 \% \mathrm{H}_{2} \mathrm{O}_{2}$ in PBS, unspecific binding was blocked by sheep serum and the $11 ß-$ HSD2 antiserum applied at a dilution of 1:1000. Incubation was carried out for $1 \mathrm{~h}$ at $37^{\circ} \mathrm{C}$. Staining was initiated by addition of the biotinylated second antibody (sheep anti rabbit), followed by strep tavid in-peroxidase and DAB as substrate chromogen solution.

Counterstaining was performed with hematoxilin. The specificity of staining was controlled by application of preimmune serum instead of the 11ß-HSD2 antiserum and additionally by blocking of the first antibody with the 11ß-HSD2 peptide.

To determine the number of Sertoli cell nuclei, transcription factor GATA-4 was used as a marker. GATA-4 is exclusively expressed in Sertoli cells (Mc Coard et al., 2001). For immunocy tochemical localization of GATA-4, a commercial purified goat anti mouse polyclonal antiserum was used (C-20: Santa Cruz Biotechnology, Santa Cruz, CA) and the sections stained as described above. To exclude unspecific binding of the second antibody, testis tissue was additionally incubated without the primary antibody as negative control. In 
addition, tissue sections were incubated with preimmune serum from goat instead of the primary antibody.

\subsection{Quantitative histological evaluations}

For evaluation of 11ß-HSD2 expression in Sertoli cells, 40 representative tubuli were analyzed. Data were related to the stage of the seminiferous epithelial cycle to clarify a possible stage-dependence for the enzyme expression (Wagner and Claus, 2004).

The total number of Sertoli cells per tubule was quantified by counting GATA-4 positive cells in 100 tubuli of each boar. Data are given as Sertoli cells per tubule. From each boar the number of 11ß-HSD2 positive Leydig cells were counted in a to tal of 250 cells.

\subsection{Quantitative real time PCR in whole testis homogenates}

Total RNA of tissue samples (25 mg) was prepared for RT using Nucleo spin ${ }^{\circledR}$ RNA II (Machery and Nagel, Düren, Germany) and checked for quantity and quality via Biopho tometer (Eppendorf, Hamburg, Germany) at an absorbance of $260 \mathrm{~nm}$ and 260/280 $\mathrm{nm}$, respectively. Reverse Transcription of $1 \mu \mathrm{g}$ of RNA was carried out in a volume of $50 \mu 1$ with the M-MLV RNAse H minus mutant (Promega, Madison, WI, USA) using random hexamer primers according to Gabler et al. (1997). To provide a negative control RT was performed with the same mixture without reverse transcriptase.

The real-time PCR was performed using the Sequence Detection System ABI Prism 7000 (Applied Biosystems, Foster City, CA) and a QuantiTect SYBR Green PCR Kit (Qiagen Hilden, Germany) in a total volume of $25 \mu 1.1 \mu 1$ PCR template (20 ng reverse transcribed total RNA) was added to $24 \mu \mathrm{l}$ of Master mix to the indicated end concentrations: $10.7 \mu 1$ water; $0.4 \mu 1$ forward primer $(0.32 \mu \mathrm{M}) ; 0.4 \mu 1$ reverse primer $(0.32 \mu \mathrm{M}) ; 12.5 \mu 1$ QuantiTect SYBR ${ }^{\circledR}$ Green PCR Master Mix (1x). Thermal cycling conditions were set as follows: first taq polymerase was activated at $95^{\circ} \mathrm{C}$ for $15 \mathrm{~min}$. The amplification segment cons is ted of 
denaturation at $95{ }^{\circ} \mathrm{C}$ for $15 \mathrm{sec}, 20 \mathrm{sec}$ of annealing at $60{ }^{\circ} \mathrm{C}$ for ubiquitin and $11 ß-\mathrm{HSD} 2$, and extension for $30 \mathrm{sec}$ at $72{ }^{\circ} \mathrm{C}$. The primer sets were as follows: ubiquitin forward primer 5'-AGATCCAGGATAAGGAAGGCAT-3' and reverse primer 5'GCTCCACCTCCAGGGTGAT-3' (198 bps, multi species primer, GenBank accession no. $\underline{\text { Z18245)}}$; 11ß-HSD2 forward primer 5'-CTCCAGTGGCCACGTACC-3' and reverse primer 5'-CACGGAAATGGCATATCTCC-3' (145 bps, GenBank accession no. $\underline{\mathbf{A 3 7 4 4 1 4}}$ ).

To evaluate specific mRNA amplification a dissociation protocol was added by slow heating from 60 to $95^{\circ} \mathrm{C}$ with a rate of $0.5^{\circ} \mathrm{C} / \mathrm{sec}$ under continuous fluorescence measurement. For the negative controls water and non-transcribed RNA were used instead of cDNA. The relative expression of each gene was calculated using the cycle threshold $(\mathrm{Ct})$ method by setting the fluorescence threshold manually at 0.2 (ABI Sequence Detector programme software version 1.1). The $\mathrm{Ct}$ is the number of PCR cycles when the fluorescence signal of the specific amplicon exceeds background fluorescence. The ubiquitin run served as internal control to check for equal quantity and quality of transcribed RNA in each reaction. The same housekeeping gene was used as internal reference for semiquantitative RT-PCR.

\subsection{RT-PCR after single cell microdissection}

The whole procedure was described before (Lekhkota et al., 2006). In brief, interstitial tissue containing, blood vessels and Leydig cells as well as total seminiferous epithelium were microdissected using the PALM Micro Beam system (PALM, Bernried, Germany). RNA from microdissected samples was extracted with the RNeasy Micro Kit (Qiagen, Hilden, Germany). Primers for $11 \beta$-HSD2 were the same as used for real time PCR. The housekeeping gene $\beta$-actin was used as internal reference for the same samples. The primer sequences for $\beta$-actin were based on a porcine sequence (GenBank accession AJ312193) 5'GGT GGA CAT CAC GAA GGA C 3'(forward) 5'TCT GCT GGA AGG TGG ACA 3' (reverse), fragment size 205bps. PCR conditions were as follows: 1 x $95{ }^{\circ} \mathrm{C}$ for $2 \mathrm{~min}, 35 \mathrm{x}$ [ 94 
${ }^{\circ} \mathrm{C}$ for $1 \mathrm{~min}, 60^{\circ} \mathrm{C}$ for $11 \beta$-HSD2 and $55^{\circ} \mathrm{C}$ for $\beta$-actin $1 \mathrm{~min}, 72{ }^{\circ} \mathrm{C}$ for $\left.1 \mathrm{~min}\right]$, and $1 \mathrm{x} 72{ }^{\circ} \mathrm{C}$ for $10 \mathrm{~min} .3 .2 \mu \mathrm{l}$ of cDNA were added to $2 \mu \mathrm{l} 10 \mathrm{x}$ PCR-buffer (including $15 \mathrm{mmol} / \mathrm{MgCl} \mathrm{M}_{2}$ Qiagen), $4 \mu 1$ 5x Q-solution, $0.4 \mu 1$ dNTPs (Promega), $0.2 \mu 1$ Taq polymerase (5U/ $\mu 1$; Qiagen), $0,8 \mu \mathrm{l}$ of each primer $(10 \mu \mathrm{mo} / 1 / 1)$, and DEPC- $\mathrm{H}_{2} \mathrm{O}$ to a final volume of $20 \mu \mathrm{l}$. PCR-products were separated on a $2 \%$ agarose gel, visualized by SYBR-Green (Sigma-Aldrich, Munich, Germany).

\section{Results}

\subsection{Antibody formation}

The development of titer was similar in the two rabbits. Antibody formation tended to rise already 2 weeks after the initial immunization but increased continuously further on due to the booster injections. A plateau was reached 14 weeks after the initial immunization

(corresponding to $3^{\text {rd }}$ booster). For immunostaining the antiserum could be used at a dilution of $1: 1000$.

\subsection{Immunocytochemical staining of $11 \beta-H S D 2$}

Examples for immunocytochemical staining are summarized in Fig. 1 for testicular tissue, kidney and colon. In interstitial tissue (upper left), immunostaining of 11ß-HSD2 was found in Leydig cells where $61.5 \%$ of cells were positive. Even stronger expression ocurred occasionally in blood vessels of the interstitium. In the tubuli, 11ß-HSD2 was expressed by Sertoli cells but appeared to occur sporadically also in spermatogonia. The average number of Sertoli cells per tubule was 27.9. From these a mean of one Sertoli cell was found to be 11ßHSD2-positive. A relationship between the number of stained Sertoli cells to one of the stages of the seminiferous epithelial cycle could not be substantiated. Incubation with preimmune serum instead of 11ß-HSD2 antiserum did not lead to positive staining (Fig. 1, upper right) thus confirming the specificity. In addition, kidney and colon revealed positive staining. 
These tissues are known to be aldosterone sensitive and thus require protection against cortisol excess.

\subsection{Western Blot}

Fig. 2 shows the Western Blot analysis of boar tissues after in cubation with 11ß-HSD2 antiserum (A) or its preimmune serum (B). In addition, the antiserum was blocked with different amounts $(1 \mu \mathrm{g}(\mathrm{C})$ or $10 \mu \mathrm{g}(\mathrm{D}))$ of the 11ß-HSD2 peptide. Only the non-blocked antiserum against 11ß-HSD2 led to a single band for each of the 3 tissues but no band was visible for the preimmune serum and the blocked 11ß-HSD2 serum. The 3 bands (Fig. 2A) had an apparent molecular mass of $40 \mathrm{kDA}$ according to the molecular size ladder which excludes a cross reactivity with $11 \beta-\mathrm{HSD} 1(34 \mathrm{kDa})$ is in agreement with data on the size of porcine 11ß-HSD2.

\subsection{Real-time PCR in whole testis homogenates and conventional RT-PCR after single cell microdissection}

The 11ßHSD-2 mRNA expression in whole testis homogenates was quantified by the ct number which indicated a moderate formation of mRNA. Mean \pm SEM was $26.69 \pm 0.33$ for 11ß-HSD2 and 17.24 \pm 0.1 for ubiquitin which was analyzed as a housekeeping gene.

Conventional RT-PCR after UV-single cell microdissection revealed an amplification product of $145 \mathrm{bps}$ for $113-\mathrm{HSD} 2$ in samples from the seminiferous epithelium as well as samples from Leydig cells and blood vessels within the interstitium (Fig. 3). 


\section{Discussion}

Only a few investigations are available on the occurrence and function of 11ß-HSD isoforms in tissues of the pig. Expression of mRNA was demonstrated in pig placental tissue (Brown et al., 2005). The activity of $11 ß-H S D 2$ was measured in pig kidney and colon by the conversion rate of cortisol to cortisone (Claus et al., 2001). More recently, RT-PCR confirmed that both 11ß-HSD1 and 11ß-HSD2 isoforms are expressed in testes of mature boars but determinations of the enzyme activity by radio-enzyme assay (Claus et al., 2005) showed, that the boar testis reveals primarily oxidative activity which catalyzes the inactivation of cortisol to cortisone whereas only low reductive activity was present.

The occurrence of oxidative activity had been also shown for Leydig cells in rodents, but the expression of 11ß-HSD2 could not be substantiated (Gao et al., 1997; Ge et al., 1997; Roland and Funder, 1996; Ge and Hardy, 2000), so that a third 11ß-HSD isoform was first suggested (Gao et al., 1997; Ge et al., 1997). More recently 11ß-HSD2 was demonstrated to occur in the smooth endoplasmatic reticulum of rat Leydig cells (Ge et al., 2005b). In the rat, it is assumed that a peripubertal change of reductive activity (11ß-HSD1) in immature an imals to oxidative activity (11ß-HSD2-like) in mature animals abolishes the inhibitory effect of cortisol on testosterone production and thus allows the pubertal rise of testosterone concentration in peripheral plasma (Welsh et al., 1982; Monder, 1990; Ge et al., 1997; Kusakabe et al., 2003).

Our data in the boar reveal considerable differences in testicular 11ß-HSD2 expression and function compared to rodents, e.g. it was possible to localize 11ß-HSD2 also in Sertoli cells, and in blood vessels of the in terstitium. The antiserum which had been raised against the porcine $11 ß-\mathrm{HSD} 2$ could be used at a high dilution and detects the protein not only in testis but also in aldosterone sensitive tissues such as kidney and colon. The specificity of the immunostaining system was also confirmed by the absence of staining, both, after preincubation with the peptide and use of preimmune serum. Also the Western Blot data 
confirm the specificity. For the first time, the enzyme could also be confirmed at the transcriptional level by real time PCR in whole testis homogenates and in Sertoli cells by conventional RT-PCR after single cell microdissection. Whereas location was confirmed by the methods applied, quantitative aspects differ considerably. Semiquantitative data derived from densitometoric PCR analysis point to similar intensity of mRNA expression in Sertoli and Leydig cells, whereas immunocytochemistry stained only a small proportion of Sertoli cells. This might be due to specific mechanisms which regulate translation into the protein but we rather assume that the sensitivity of the immunocytochemical method is limited and only detects high concentrations of the protein. Such differences in the sensitivity may also explain why immunocytochemistry detected protein formation in only about $60 \%$ of Leydig cells. Alternatively different populations of adult Leydig cells with different functional status were described for rats (Mendis-Handagama and Ariyaratne, 2001) and might also explain why not all Leydig cells were stained in boar testes.

A role of 11ß-HSD2 for steroid biosynthesis in mature boars was not detected so far and is unlikely to exist because GR is absent in Leydig cells of mature boars of different ages (Wagner and Claus, 2004 and unpublished data). Rather the expression of 11ß-HSD2 may be related to the occurrence of the GR in spermato gonia which again is linked to the degree of apoptosis of germ cells and thus overall sperm yield. The expression in several cell types such as Leydig cells and Sertoli cells and in blood vessels may rather represent several lines of defense to protect spermatogonia against cortisol and thus apoptosis.

In isolated rat Leydig cells, additionally the expression of mineralocortic oid receptor (MR) was demonstrated and a role of aldosterone for testosterone production substantiated. The oxidative inactivation of glucocortico ids thus might avo id interaction with the MR (Ge et al., 2005b). In the pig, expression of MR in Leydig cells so far was not demonstrated.

Because we could demonstrate that active immunization against GnRH led to a drop of LH but not FSH and simultaneously to a drop of 11ß-HSD2 activity in testis homogenates (Claus 
et al., 2005), regulation of this enzyme is independent on FSH. Sertoli cells do not contain LH receptors in the pig, so that expression in these cells is likely to be regulated by androgens and/or es trogens. In case of Leydig cells which contain LH receptors a direct function of LH is not excluded. In a recent study infusion of estradiol (Wagner et al., 2006) in immunized boars only led to a minor increase in $11 \beta-H S D 2$ activity probably due to expression in Sertoli cells which are responsive to estradiol by the expression of $\operatorname{Er} 3$ (Lekhkota et al., 2006).

\section{Acknowledgement}

The authors would likte to thank Dr. J. Mönchenberger for immunization of rabbits and blood sampling as well as Mrs. H. Hägele, C. Ostertag and S. Mayer for technical assistance.

\section{References}

Albiston, A.L., Obeyesekere, V.R., Smith, R.E., Krozowski, Z.S., 1994. Cloning and tissue distribution of the human 11ß-hydroxysteroid dehydrogenase type 2 enzyme. Mol. Cell. Endocrinol. 105, 11-17.

Bradford, M.M., 1976. A rapid and sensitive method for the quantitation of microgram, quantities of protein utilizing the principles of proteindye binding. Anal. Biochem. 72, $248-254$

Brown, R.W., Chapman, K.E., Edwards, C.R.W., Seckl, J.R., 1993. Human placental 11ßhydroxysteroid dehydrogenase: evidence for and partial purification of a distinct NADdependent isoform. Endocrinology 132, 2614-2621.

Brown, R.W., Seckl, J.R., 2005. Glucocorticoid action in development. Curr. Opin. Endocrinol. Diab. 12, 224-232.

Burns, J.A., Burtler, C., Moran, J., Whitesides, G.M., 1991. Selective reduction of disulfides by Tris(2-carboxyethyl)phosphine. J. Org. Chem. 56, 2648-2650. 
Claus, R., Raab, S., Lacorn, M., 2001. Acitivities of 11ß-Hydroxystero id-Dehydrogenase 2 in different regions of the intestinal tract of pigs. J. Exp. Endocr. Diab. 109, 374-377.

Claus, R., Wagner, A., Lambert, T., 2005. Characterization of 11ß-hydroxysteroid dehydrogenase activity in testicular tis sue of normal and GnRH-immunized boars as a possible regulator of spermatogenesis. Exp. Clin. Endocr. Diab. 113, 262-267.

Draper, N., Stewart, P.M., 2005. 11ß-hydroxysteroid-dehydrogenase and the pre-receptor regulation of corticosteroid hormone action. J. Endocr. 186, 251-271.

Funder, J.W., Pearce, P.T., Smith, R., Smith, A.I., 1988. Min eralocorticoid action: target tissue specificity is enzyme, not receptor, mediated. Science $242,583-585$.

Gabler, C., Lauer, B., Einspanier, A., Schams, D., Einspanier, R., 1997. Detection of mRNA and immunoreactive proteins for acidic and basic fibroblast growth factor and expression of the fibroblast growth factor receptors in the bovine oviduct. J. Reprod. Fert. 109, 213-221.

Gao, H.-B., Ge, R.-S., Lakshmi, V., Marandici, A., Hardy, M.P., 1997. Hormonal regulation of oxidative and reductive activities of 11ß-Hydroxys teroid dehydrogenase in rat leydig cells. Endocrinol. 138, 156-161.

Ge, R.-S., Dong, Q., Niu, E.-M., Sottas, C.M., Hardy, D.O., Catterall, J.F., Latif, S.A., Morris, D.J., Hardy, M.P., 2005a. 11ß-hydroxysteroid dehydrogenase 2 in rat Leydig cells: its role in blunting glucocorticoid action at physiological levels of substrate. Endocrinology $146,2657-2664$.

Ge, R.-S., Dong, Q., Sottas, C.M., Latif, S.A., Morris, D.J., Hardy, M.P., 2005b. Stimulation of testosterone production in rat Leydig cells by aldosterone is mineralocorticoid receptor mediated. Mol. Cell. Endocr. 243, 35-42.

Ge, R.-S., Gao,H.-B., Nacharaju, V.L., Gunsalus, G.L., Hardy, M.P., 1997. Identification of a kinetically distinct activity of $11 ß$-hydroxysteroid dehydrogenase in rat Leydig cells. Endocrinology 138, 2435-2442. 
Ge, R.S., Hardy, M.P., 2000. Initial predominance of the oxidative activity of type $111 ß-$ hydroxysteroid dehydrogenase in primary rat Leydig cells and transfected cell lines. J. Androl. 21, 303-310.

Geley, S., Fiegl, M., Hartmann, B.L., Kofler, R., 1996. Genes mediating glucocorticoid effects and mechanisms of their regulation. Rev. Physiol. Bioch. Pharmacol. 128, 1-97.

Holmes, M.C., Seck1, J.R., 2006. The role of 11ß-hydroxysteroid dehydrogenase in the brain. Mol. Cell. Endocrinol. 248, 9-14.

Klemcke, H.G., Sampath Kumar, R., Yang, K., Vallet, J.L., Christenson, R.K., 2003. 11ßhydroxysteroid dehydrogenase and glucocorticoid receptor messenger RNA expression in porcine placentae : effects of stage of gestation, bree, and uterine environment. Biol. Reprod. 69, 1945-1950.

Kusakabe, M., Nakamura, I., Young, G., 2003. 11ß-hydroxysteroid dehydrogenase complementary deoxyribonucleic acid in rainbow trout: cloning, sites of expression, and seasonal changes in gonads. Endocrinol. 144, 2534-2545.

Lange, F., Aigner, B., Müller, M., Claus, R., 2003. Porcine 11ß-hydroxysteroid dehydrogen ase type 2 isoform: complete coding sequence and polymorphisms. Anim. Bio technol. 14, 13-17.

Leckie, C.M., Welberg, L.A.M., Seck1, J.R., 1998. 11ß-hydroxysteroid dehydrogenase is a predominant reductase in intact rat Leydig calls. J. Endocr. 159, 233-238.

Lekhkota, O., Brehm, R., Claus, R., Wagner, A., Bohle, R.M., Bergmann, M., 2006: Cellular localization of estrogen receptor alpha $(E R \alpha)$ and estrogen receptor beta $(E R \beta)$ in the boar testis. Histochem. Cell Biol. 125, 259-264.

McCoard, S.A., Lunstra, D.D., Wise, T.H., Ford, J.J., 2001. Specific staining of Sertoli cell nuclei and evaluation of Sertoli cell number and proliferative activity in Meishan and White composite boars during the neonatal period. Biol. Reprod. 64, 689-695. 
Mendis-Handagama, S.M., Ariyaratne, H.B., 2001. Differentiation of the adult Leydig cell population in the postnatal testis. Biol. Reprod. 65, 660-671.

Mentschel, J., Leiser, R., Mülling, C., Pfarrer, C., Claus, R., 2001. Butyric acid stimulates rumen mucosa development in the calf mainly by a reduction of apoptosis. Arch. Anim. Nutr. 55, 85-102.

Michael, A.E., Thurston, L., Rae, M.T., 2003. Glucocorticoid metabolism and reproduction: a tale of two enzymes. Reproduction 126, 425-441.

Monder, C., 1990. Characterization and biological significance of corticosteroid 11ßdehydrogenase, the oxidizing component of 11 beta-hydroxysteroid dehydrogen ase. Ann. NY Acad. Sci. 595, 26-39.

Monder, C., Miroffy, A., Marandici, A., Hard, U.P., 1994. 11ß-hydroxysteroid dehydrogenase alleviates glucocorticoid mediated inhibition of steroidogenesis in rat Leydig cells. Endocrinology 134, 1199-1204.

Monder, C., White, P.C., 1993. 11 beta-hydroxysteroid dehydrogenase. Vitam. Horm. 47, $187-271$

Moran, T.J., Gray, S., Mikosz, C.A., Conzen, S.D., 2000. The glucocorticoid receptor mediates a survival signal in human mammary epithelial cells. Cancer Res. 60, 867-872.

Naray-Fejes-Toth, A., Fejes-Toth, G., 1995. Expression cloning of the aldosterone target cellspecific 11 beta-hydroxysteroid dehydrogenase from rabbit collecting duct cells. Endocrinology 136, 2579-2586.

Neumann, A., Haider, S.G., Hilscher, B., 1993. Temporal coincidence of the appearance of elongated spermatids and of his tochemical reaction of 11ß-hydroxysteroid dehydrogenase in rat Leydig cells. Andrologia 25, 263-269.

Ozols, J., 1995. Lumenal orientation and post-translational modifications of the liver microsomal 11 beta-hydroxysteroid dehydrogenase. J. Biol. Chem. 270, 2305-2312. 
Phillips, D.M., Lakshmi, V., Monder, C., 1989. Corticosteroid 11ß-dehydrogenase in rat testis. Endocrinology 125, 209-216.

Riccardi, C., Cifone, M.G., Migliorati, G., 1999. Glucocorticoid hormone-induced modulation of gene expression and regulation of T-Cell death: role of GITR and GILZ, two dexamethasone-induced genes. Cell Death Diff. 6, 1182-1189.

Rogatsky, I., Trowbridge, J.M., Garabedian, M.J., 1997. Glucocorticoid receptor-mediated cell cycle arrest is achieved through distinct cell-specific transcriptional regu latory mechanisms. Mol. Cell Biol. 17, 3181-3193.

Roland, B.L., Funder, J.W., 1996. Localization of 11ß-hydroxysteroid dehydrogenase type 2 in rat tissues. In situ studies. Endocrinol. 137, 1123-1128.

Romeis, B., 1989. Mikroskopische Technik. P. Böck (edt), Urban und Schwarzenberg, München, $17^{\text {th }}$ ed., chapt. 5, pp 113-133.

Rothbard, J.B., Fernandez, R., Schoolnik, G.K., 1984. Strain-specific and common epitopes of gonococcal pili. J. Exp. Med. 160, 208-221.

Sanchez, I., Goya, I., Vallerga, A.K., Firestone, G.L., 1993. Glucocorticoids reversibly arrest rat hepatoma cell growth by inducing an early G1 block in cell cycle progression. Cell Growth Diff. 4, 215-225.

Seckl, J.R., 1997. 11 beta-hydroxysteroid dehydrogenase in the brain : a novel regulator of glucocorticoid action? Front. Neuroendocrinol. 18, 49-99.

Thompson, E.B., 1994. Apoptosis and steroid hormones. Mol. Endocrinol 8, 665-673.

Wagner, A., Lock, M., Bergmann, M., Lekhkota, O., Claus, R., 2006. Effects of estradiol infusion in GnRH immunized boars on spermatogenesis. J. Androl. 27, 880-889

Wagner, A., Claus, R., 2004. Involvement of glucocorticoids in testicular involution after immunization of boars again st GnRH. Reproduction 127, 275-283.

Welsh, T.H., Bambino, T.H., Hsueh, A.J.M., 1982. Mechanism of glucocortico id-induced suppression of testicular androgen biosynthesis. Biol. Reprod. 28, 1138-1146. 
Page 20 of 28 


\section{Figure legends:}

Fig. 1. Immunocytochemical staining of 11ß-HSD2 in testes and aldosterone sensitive tissues (colon, kidney). Upper left: Positive staining in testicular tubuli (arrow: stained Sertoli cell). Upper right: Testis tissue incubated with preimmune serum. Lower left: Renal tissue incubated with 11ß-HSD2 antiserum. Lower right: Colon tissue incubated with 11ß-HSD2 antiserum.

Fig. 2. Western blot analysis of boar tissues after incubation with 11ß-HSD2 antiserum (A), preimmune serum (B) as well as after preabsorption with $1 \mu \mathrm{g}(\mathrm{C})$ and $10 \mu \mathrm{g}(\mathrm{D})$ of the 11ß-HSD2 peptide antigen in testis (1), colon (2), and kidney (3). 11ß-HSD2 specific antiserum reacted with a single band of an apparent molecular mass of approximately $40 \mathrm{kDa}$ (arrow). Lanes 1-3 were loaded with $15 \mu \mathrm{g}$ of whole protein extract. M: Protein standard as molecular size marker (kDA).

Fig.: 3 RT-PCR from tissue samples collected by UV-single cell microdissection. a: mRNA expression of $\beta$-actin, b: mRNA-expression of 11ßHSD2. lane 1: sample of blood vessels, lane 2: sample of interstitial tis sue containing Leydig cells, lane 3: sample of total seminiferous epithelium, M: 100bps DNA-ladder. 


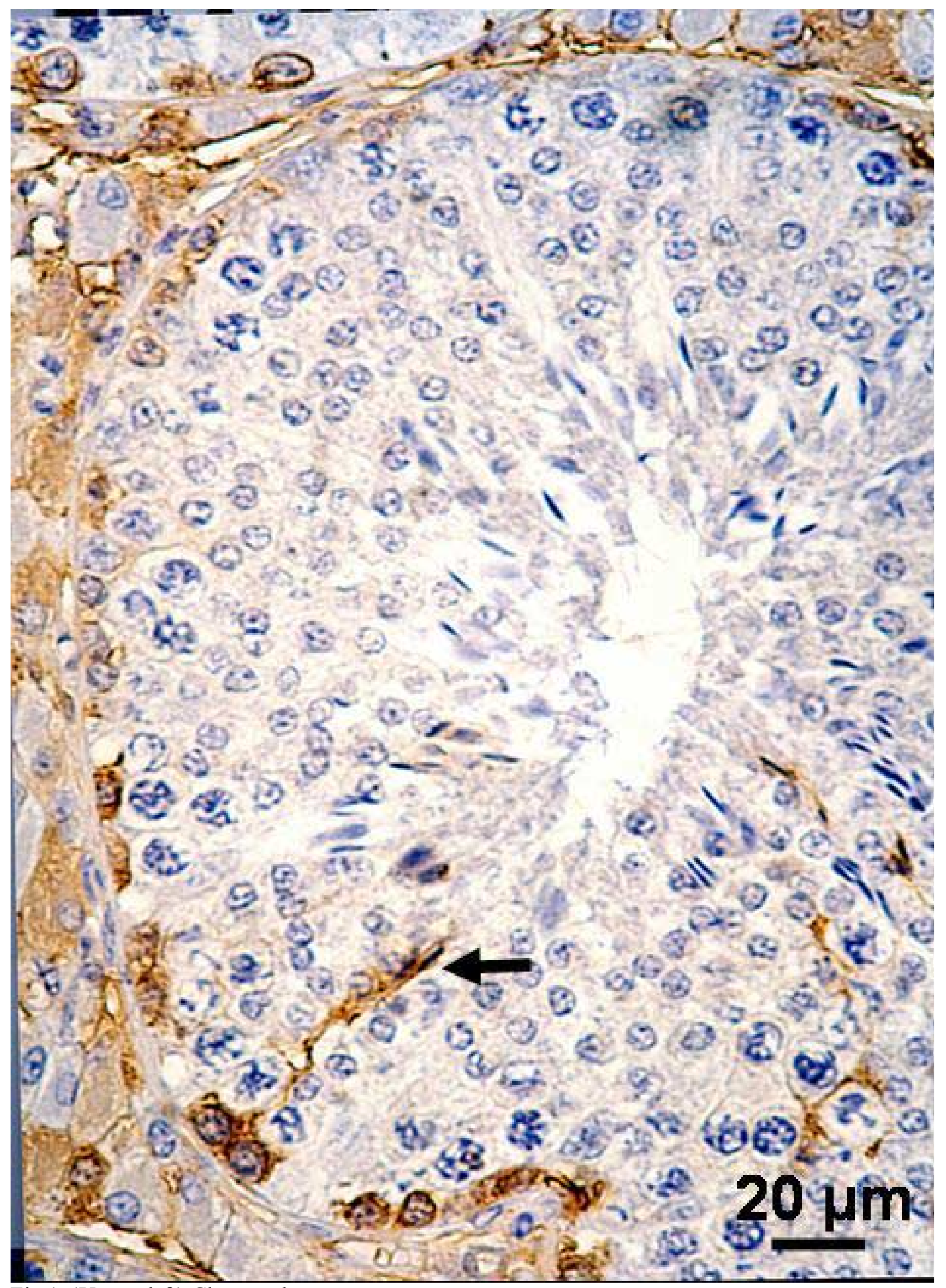

Fig.1. (Upper left) Claus et al 


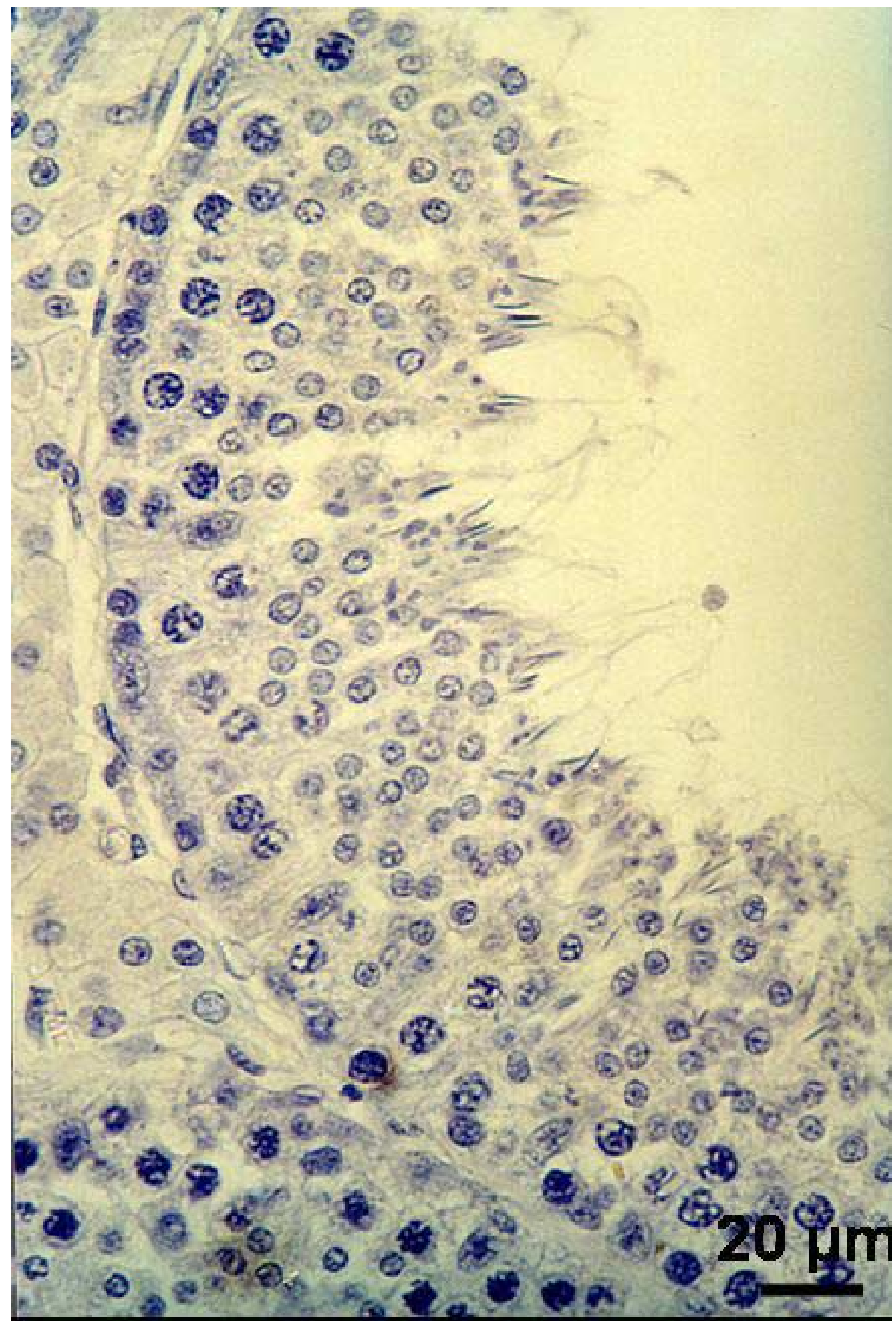

Fig 1. (Upper right) Claus et al. 


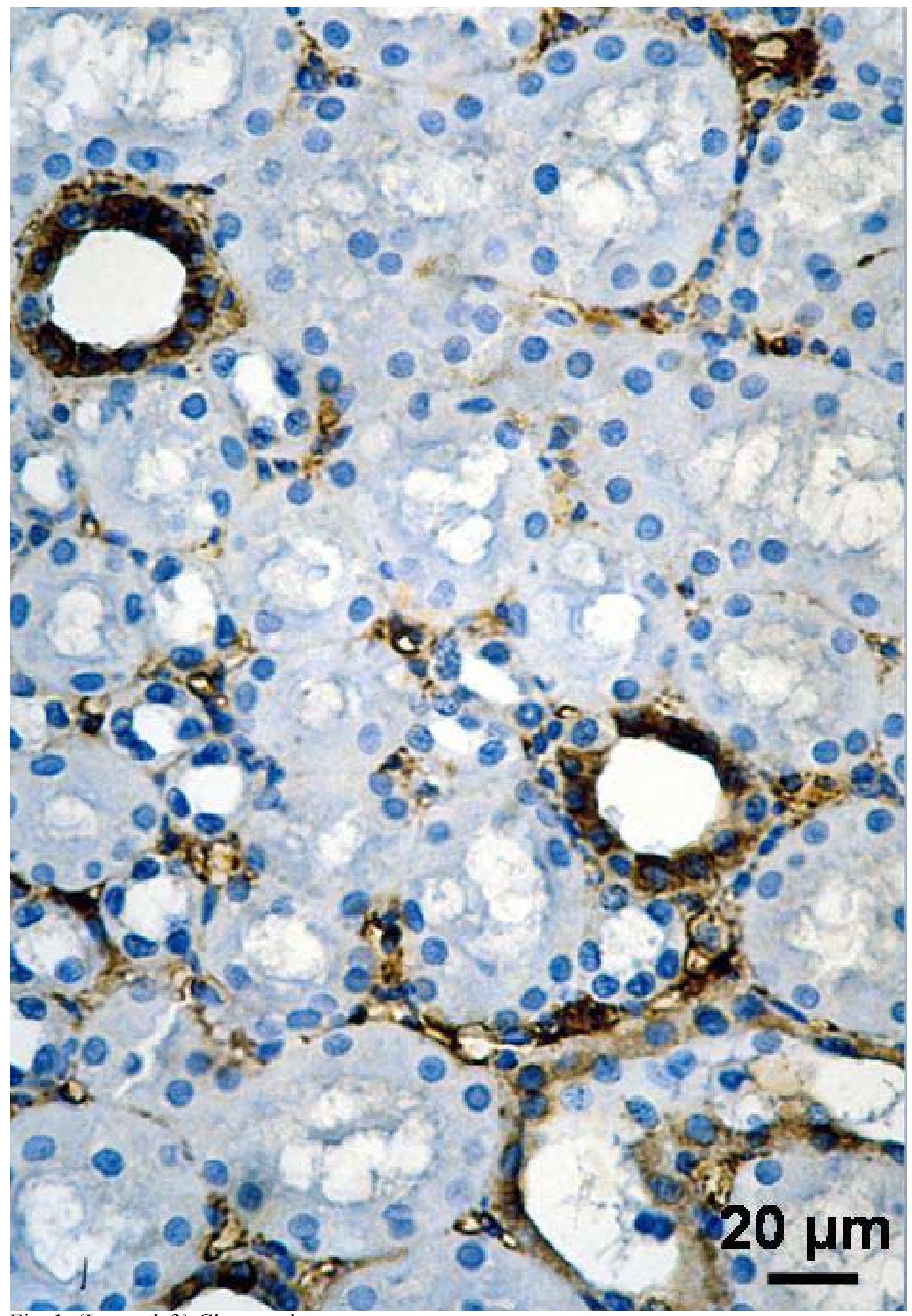

Fig. 1. (Lower left) Claus et al. 


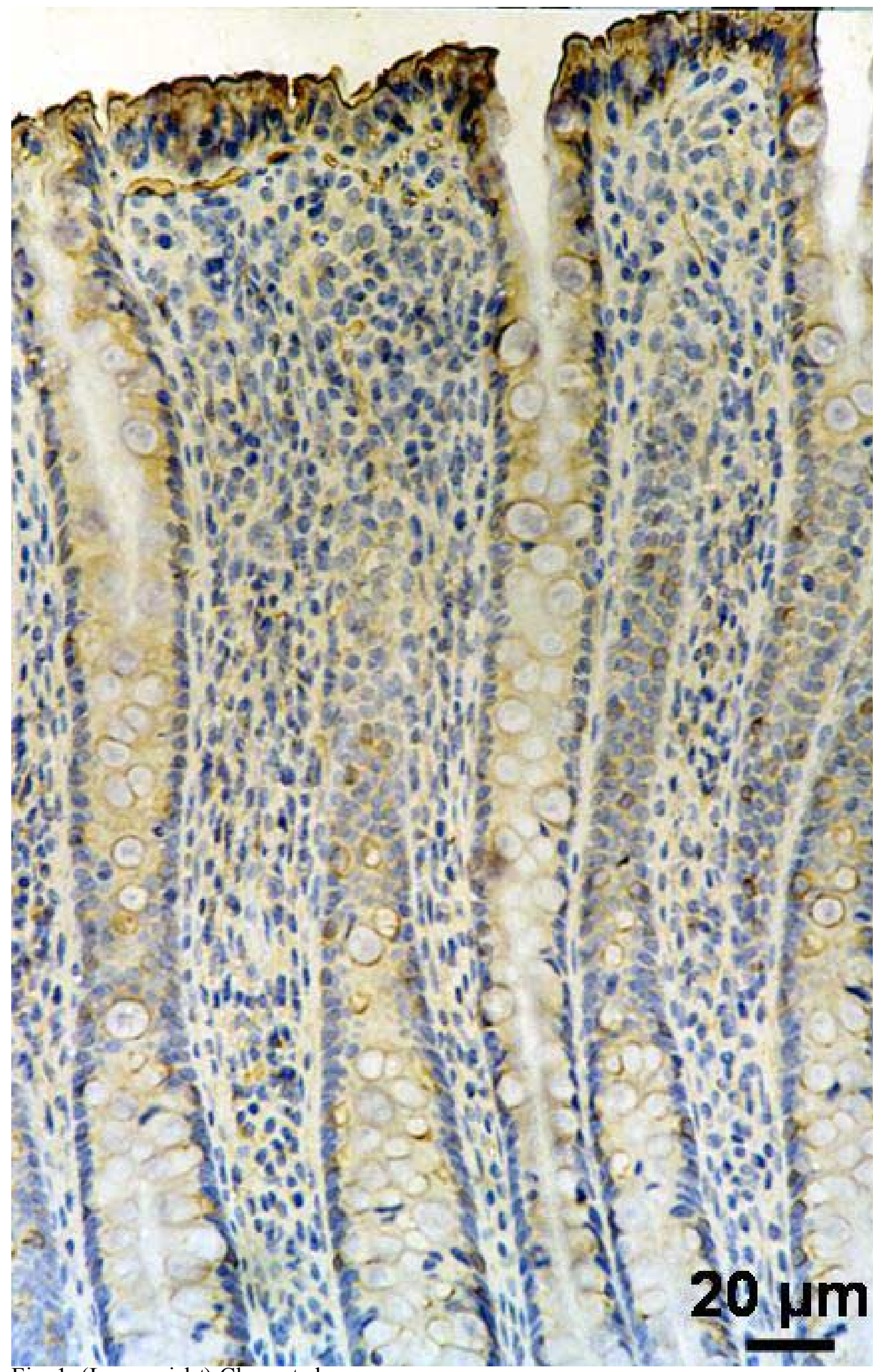

Fig. 1. (Lower right) Clau s et al. 


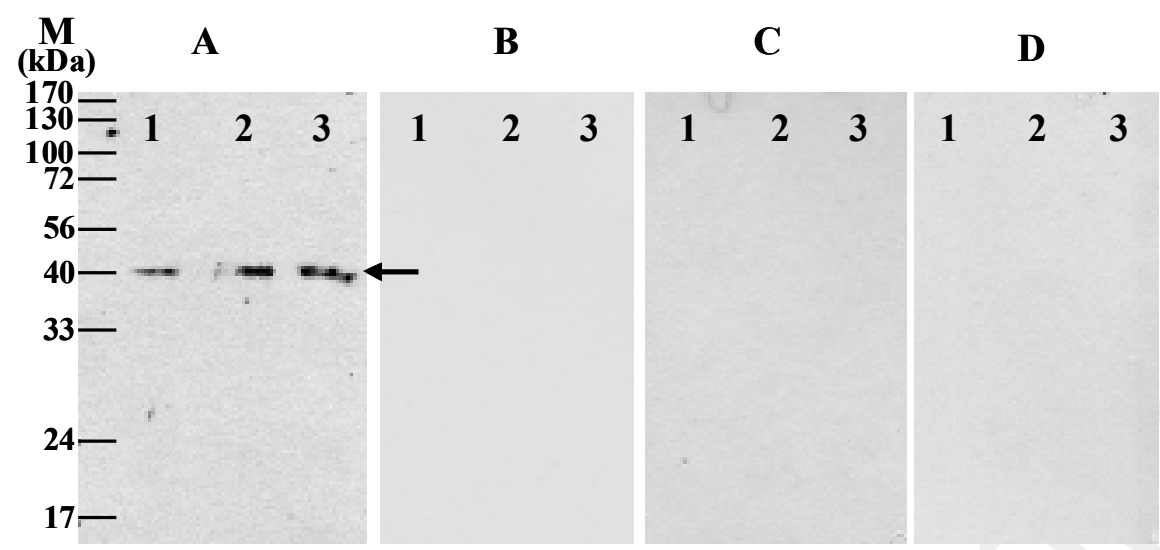

Fig. 2. Claus et al. 


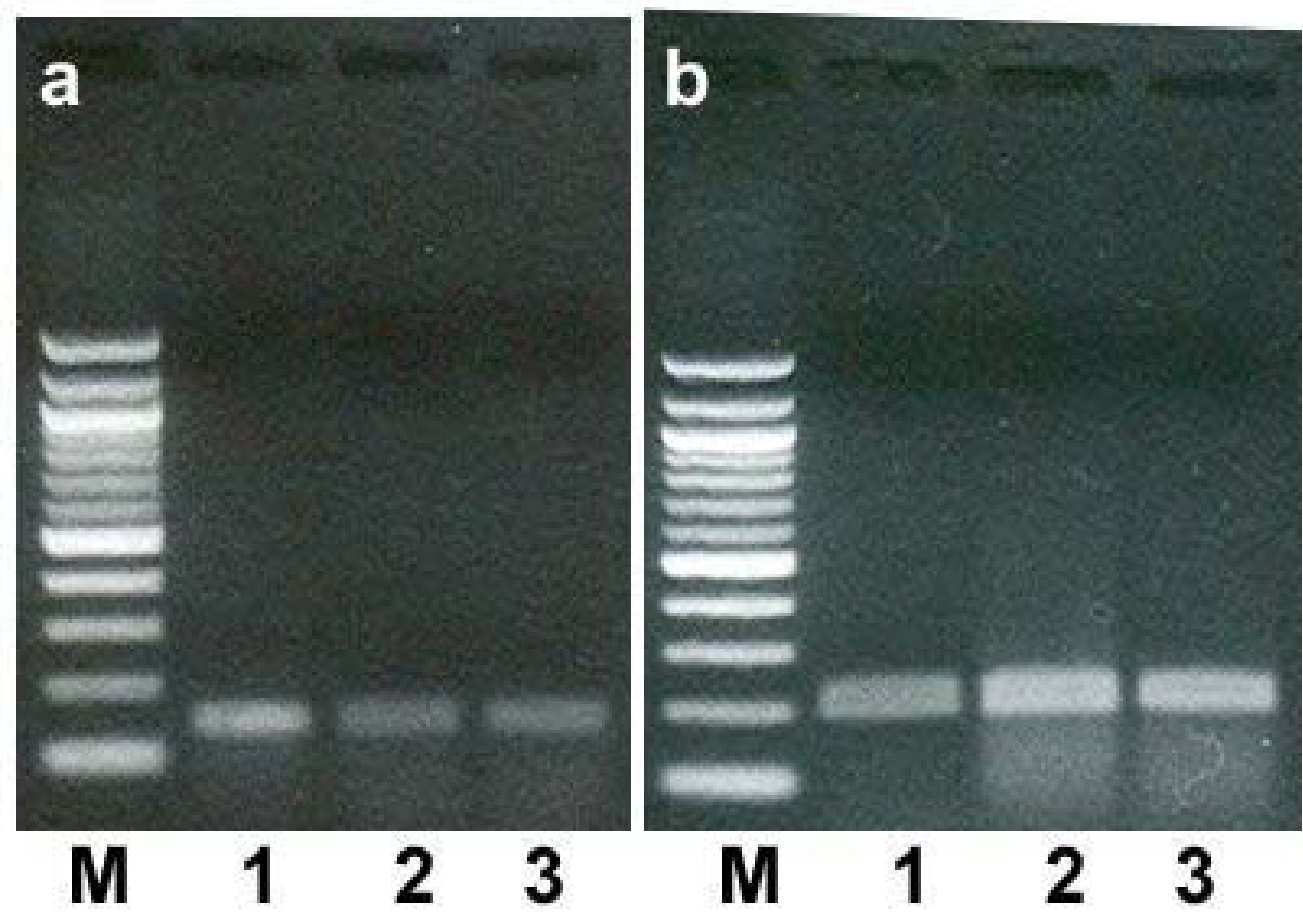

Fig. 3 Claus et al. 


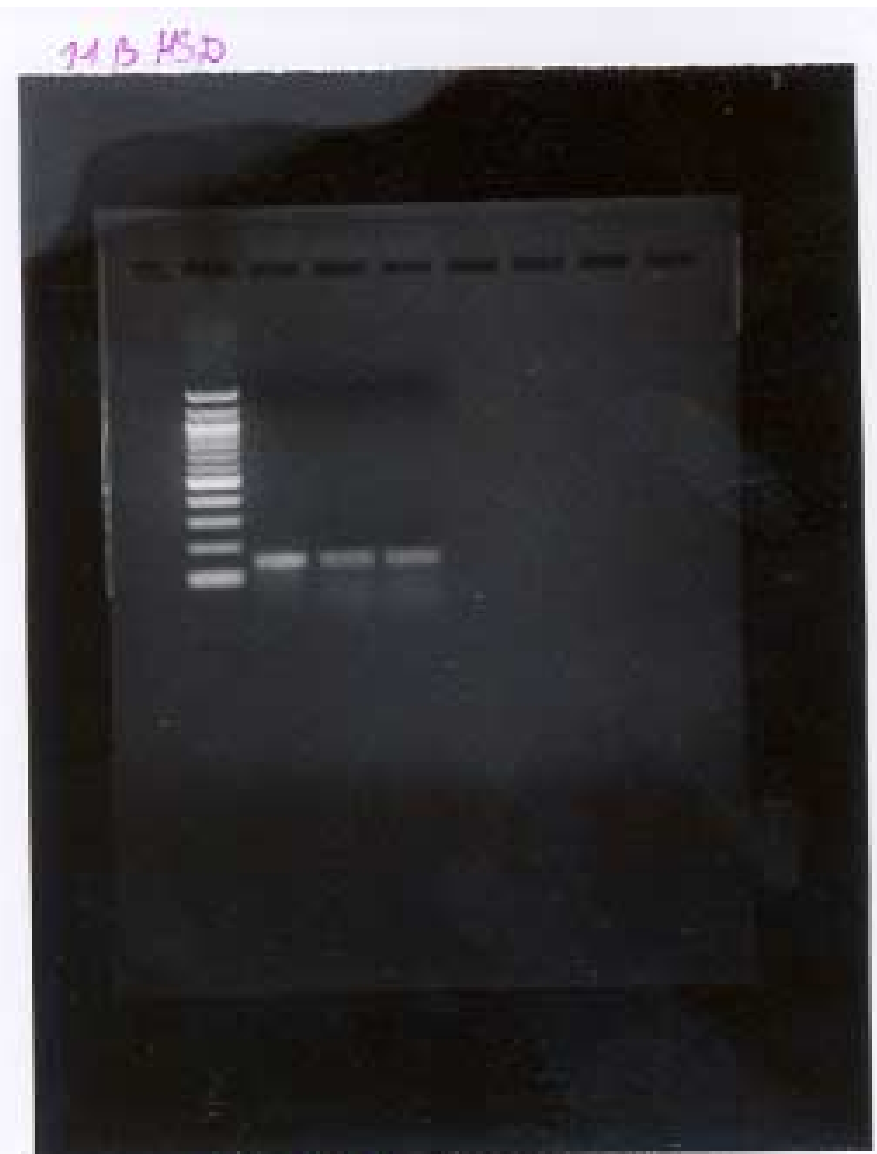

$B G l_{2}$ Tub

123
$B$ Act icell Pres.

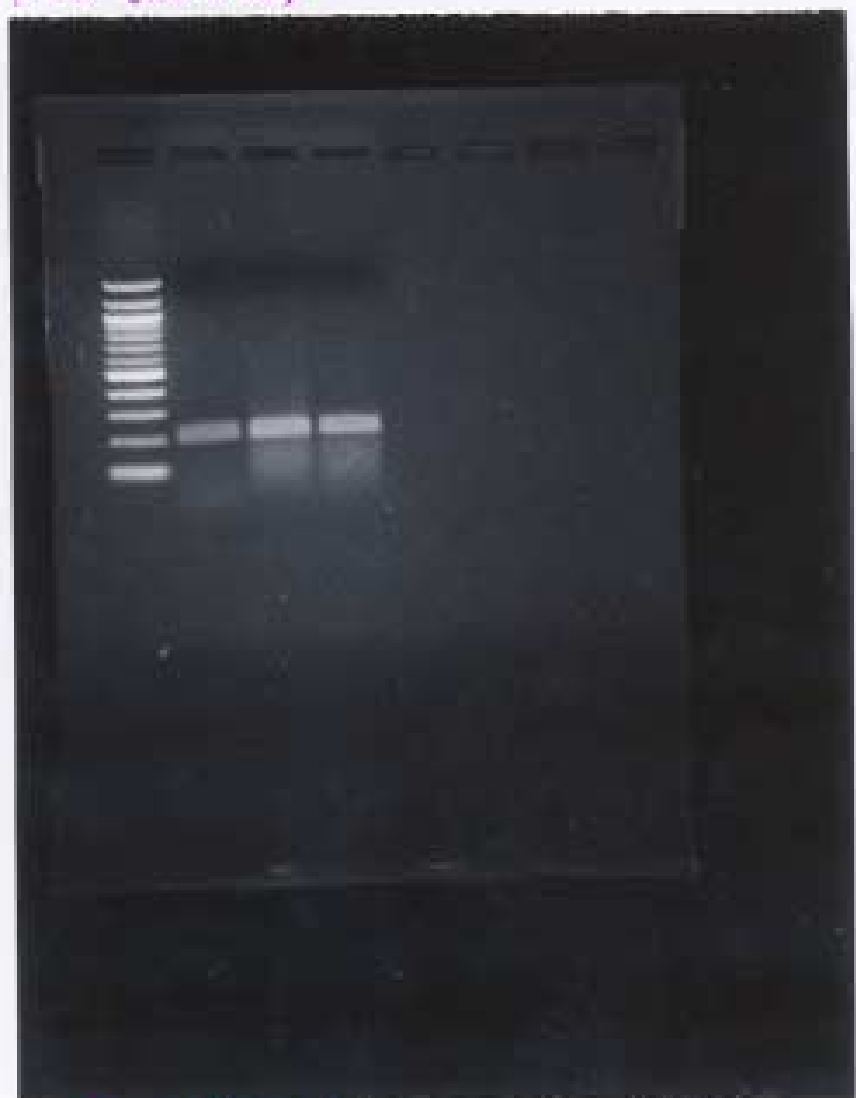

$M \quad b 6<$ Tub

123 